Vol. 9 (2000): 303-318.

\title{
Responses of soil respiration and barley growth to modified supply of oxygen in the soil
}

\author{
Asko Simojoki \\ Department of Applied Chemistry and Microbiology, PO Box 27, FIN-00014 University of Helsinki, Finland, \\ e-mail: asko.simojoki@helsinki.fi
}

\begin{abstract}
Roots of dry-land plants are supplied with oxygen mainly by molecular diffusion from soil air. Roots may suffer from hypoxia if soil aeration is reduced by compaction and wetting. Although the mechanisms involved are well known, more research is needed to relate soil aeration status to plant growth. The effects of reduced oxygen supply on soil respiration and the growth of barley seedlings were studied in pot experiments with fine sand soil, where the soil air composition was varied by flushing the soil with gas streams containing $0 \%, 2 \%, 6 \%, 10 \%$ or $20 \% \mathrm{O}_{2}$ independently of compactness (bulk density $1.4,1.6 \mathrm{Mg} \mathrm{m}^{-3}$ ) and wetness (air space $0-5 \%,>5 \%$ ). Plant growth decreased only at $0-$ $2 \% \mathrm{O}_{2}$ in the loose moist soil but as early as $20 \% \mathrm{O}_{2}$ in the wet soil. Soil compaction impaired plant growth regardless of wetting and aeration. In the loose moist soil cropped with barley, the respiration rate (emission of $\mathrm{CO}_{2}$ ) did not decrease at $6 \% \mathrm{O}_{2}$ but decreased clearly at $0-2 \% \mathrm{O}_{2}$. The results compared fairly well with the critical oxygen concentrations calculated by a simple multicylindrical model, in which the water-film thickness around the roots was estimated using soil water retention data.
\end{abstract}

Key words: critical oxygen concentration, diffusion models, Hordeum vulgare, roots, soil air

\section{Introduction}

Roots of all plant species require oxygen for growth, and those of dry-land species depend mainly on the oxygen supply from the soil (Armstrong 1979). Hutchins (1926) was among the first to draw attention to the dynamic nature of the oxygen supplying power of the soil, or to rates at which the soil can deliver oxygen to respiring organisms. Insufficient aeration is gen- erally a problem for crop growth only in wet soils (see Stępniewski et al. 1994). Despite much research done on soil aeration (see Gliński and Stępniewski 1985, Jaakkola and Simojoki 1998, Simojoki and Jaakkola 2000) and plant physiological responses to oxygen deficiency (reviewed by Drew 1990, Drew 1992, Vartapetian and Jackson 1997), development of reliable methods for estimating soil aeration status in a way that relates to plant growth still remains an important goal (Drew 1992). The structural deterioration 


\section{AGRICULTURAL AND FOOD SCIENCE IN FINLAND}

Simojoki, A. Supply of oxygen to plant roots in the soil

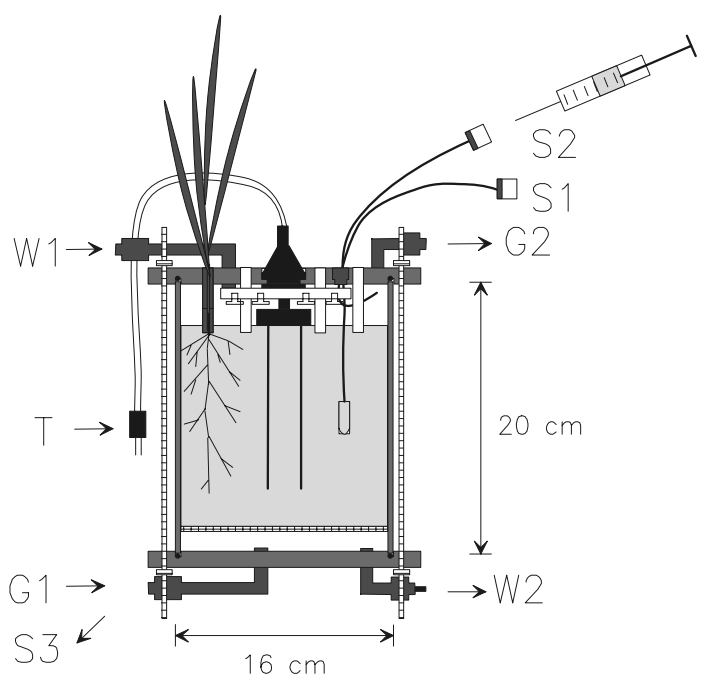

Fig. 1. The construction of the experimental pot. An exemplary barley plant, sown in the tubes (sealed with silicone products) of the lid, is shown with roots growing into the soil. Connectors: G1 gas inlet; G2 gas outlet; W1 watering; W2 removal of excess water; S1, S2 and S3 sampling of air; $\mathrm{T}$ time domain reflectometry probe (not discussed in this study).

of soils can reduce soil aeration in mechanized agriculture (Stępniewski et al. 1994), which emphasizes the importance of the subject.

Much of the previous research has been done by relating oxygen diffusion rate (ODR) measurements with buried Pt-electrodes to plant growth. The strong correlation between ODR measurements and plant performance (Gliński and Stępniewski 1985) emphasizes the importance of an adequate diffusive flux of oxygen from soil air to plant roots. Numerous mechanistic models have been constructed to describe the various aspects of root aeration in the soil (Lemon 1962, de Willigen and van Noordwijk 1984, Armstrong et al. 1994). However, rather little attention has been given to the properties of soil which determine the flux. Obviously variables such as water retention properties, moisture contents, air-filled porosities, bulk densities and $\mathrm{O}_{2}$ concentrations in soil air are involved. The lack of this information makes comparisons with earlier experimental results difficult.

In this study, the aim was to get empirical data on the effects of reduced oxygen supply on the growth and respiration of barley seedlings in fine sand soil, where the oxygen supply to roots was modified by varying the concentrations of oxygen in soil air independently of compaction and wetness. The oxygen concentrations that were found to be too small for the growth and respiration of barley were compared to the theoretical critical oxygen concentrations given by simple multicylindrical models (Lemon 1962, Armstrong and Beckett 1985) on oxygen diffusion from soil air to roots. The thickness of water film around roots, an important parameter of the model, was estimated in a new way by employing the average distance between the airfilled pores as calculated from the moisture content and water retention curve of the soil.

\section{Material and methods}

\section{Soil, plant and environmental conditions}

Plastic pots (polyvinyl chloride tube, outer diameter $160 \mathrm{~mm}$, wall $4 \mathrm{~mm}$ ) were designed and built for this study. The design allowed the packing of soil to different bulk densities, flushing the soil with gas streams (forced aeration), watering the soil, measurements of soil air composition and gaseous emissions, and easy soil sampling (Fig. 1).

Soil taken from a plough layer of a field tentatively classified as Typic Cryochrept (Soil Survey Staff 1992) at the Kotkaniemi Experimental Farm of Kemira Oy in Vihti $\left(60^{\circ} 21^{\prime} \mathrm{N}\right.$, $24^{\circ} 23^{\prime} \mathrm{E}$ ) was sieved with a $5 \mathrm{~mm}$ mesh screen and homogenized. The average particle size composition was $10 \%$ clay $(<2 \mu \mathrm{m}), 9 \%$ silt $(2-20$ $\mu \mathrm{m})$, and $59 \%$ fine sand $(20-200 \mu \mathrm{m})$. The particle density was $2.59 \mathrm{Mg} \mathrm{m}^{-3}$. On average, the soil contained $2.5 \%$ organic carbon, $0.17 \%$ total nitrogen and $41 \mathrm{mg} \mathrm{kg}^{-1}$ mineral nitrogen (ammonium + nitrate). The soil was limed with 2.1 $\mathrm{g} \mathrm{kg}^{-1}$ of $\mathrm{CaCO}_{3}$ to raise the $\mathrm{pH}$ from 5.3 to 6.5 (in $0.01 \mathrm{M} \mathrm{CaCl}_{2}$ suspension) and fertilized with 
Vol. 9 (2000): 303-318.

nutrient salts containing $\left(\mathrm{mg} \mathrm{pot}^{-1}\right) 540 \mathrm{~N}, 216$ $\mathrm{P}, 540 \mathrm{~K}, 108 \mathrm{Mg}$ and adequate amounts of other nutrients.

The soil at the water content $\left(\theta_{w}\right)$ of 0.225 or $0.197 \mathrm{~kg} \mathrm{~kg}^{-1}$ was packed in the pots to a final volume of $2.72 \mathrm{dm}^{3}$ (depth $15 \mathrm{~cm}$ ) at dry bulk densities $\left(\rho_{\mathrm{b}}\right)$ of 1.39 or $1.59 \mathrm{Mg} \mathrm{m}^{-3}$, respectively. This was done with a compression testing maching (Model MC-1000) equipped with a potentiometric displacement sensor. The compaction levels are here referred to as loose or compact treatment, respectively. Such compaction reduced the total porosity (saturated water content) and the amount of large pores with an equivalent diameter larger than $30 \mu \mathrm{m}$ (Fig. 2).

Both uncropped and cropped pots were included in the study. At sowing, one pre-germinated barley seed (Hordeum vulgare L. cv. Kymppi) was placed in contact with soil in each of the 24 small acrylic tubes (inner diameter 7 $\mathrm{mm}$ ) in the upper lid of the pot. After the barley sprouted, the tubes were sealed air-tight with silicone products (Sylgard ${ }^{\circledR} 527$ Dow Corning, Elastosil $^{\circledR}$ M4601 Wacker-Chemie).

The experiments were carried out in 19941995 in phytotrons (floor $2.0 \mathrm{~m} \times 2.0 \mathrm{~m}$, height $1.9 \mathrm{~m}$ ). Day and night temperatures were $20^{\circ} \mathrm{C}$ and $15^{\circ} \mathrm{C}$, respectively. The intensities of photosynthetically active radiation were $160 \mu \mathrm{mol}$ $\mathrm{m}^{-2} \mathrm{~s}^{-1}$ on the upper lid of the pot and $240 \mu \mathrm{mol}$ $\mathrm{m}^{-2} \mathrm{~s}^{-1}$ at the longest leaves of barley for $14 \mathrm{~h}$ daily. Full darkness lasted for $8 \mathrm{~h}$.

\section{Experimental designs}

In a set of three experiments (Nos. 1-3, 88 pots in total), the loose and compact soils were subjected to combinations of cropping (uncropped or cropped with barley), wetting (wet or moist soil) and forced aeration $(0 \%, 2 \%, 10 \%$ or $20 \%$ of $\mathrm{O}_{2}$ in $\mathrm{N}_{2}$ ). Each experiment included additional 2-4 pots that were harvested just before starting the wetting and aeration treatments, and four open pots (no upper lid, cropped loose soil) that received no gas flow.

The wetting and aeration treatments were

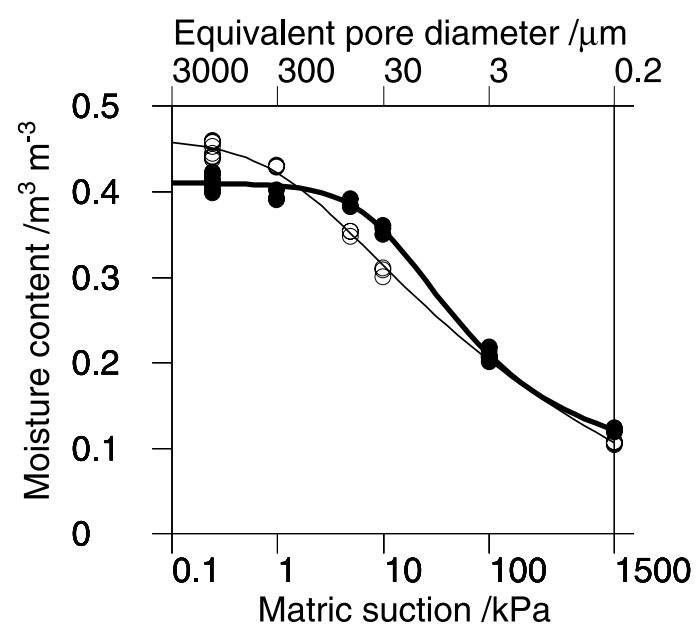

Fig. 2. Water retention curves (drying curves) in the loose soil (thin line) and in the compact soil (thick line). The parameters $\theta_{\mathrm{r}}, \theta_{\mathrm{s},} \alpha$ and $\mathrm{N}$ of van Genuchten (1980) equation $\theta=\theta_{\mathrm{r}}+\left(\theta_{\mathrm{s}}-\theta_{\mathrm{r}}\right) /\left(1+\left(\alpha \psi_{\mathrm{m}}\right)^{\mathrm{N}}\right)^{(1-1 / \mathrm{N})}$ fitted to the data are $-0.101,0.461,0.82 \mathrm{kPa}^{-1}$ and 1.14 in the loose soil and $0.079,0.410,0.090 \mathrm{kPa}^{-1}$ and 1.42 in the compact soil, respectively. $\theta$ volumetric moisture content, $\psi_{\mathrm{m}}$ matric suction.

started at 11-12 days after the sowing, and continued until the end of the experiment. The soil was maintained either wet $\left(\theta_{\mathrm{w}}=0.30-0.32\right.$ $\mathrm{kg} \mathrm{kg}^{-1}$ in the loose soil, $\theta_{\mathrm{w}}=0.24 \mathrm{~kg} \mathrm{~kg}^{-1}$ in the compact soil) or moist $\left(\theta_{\mathrm{w}}=0.23-0.26 \mathrm{~kg} \mathrm{~kg}^{-1}\right.$ in the loose soil, $\mathrm{q}_{\mathrm{w}}=0.20 \mathrm{~kg} \mathrm{~kg}^{-1}$ in the compact soil) by weighing and watering the pots daily. The composition of soil air was regulated by conducting a gas stream of known $\mathrm{O}_{2}$ concentration in $\mathrm{N}_{2}$ at a constant rate of c. $25 \mathrm{ml}_{\mathrm{n}}$ $\mathrm{min}^{-1}$ (Brooks rotameter GT1355 + flow controller 8940) from the bottom of the pot through the soil (Fig. 1).

In another experiment (No. 4, 16 pots in total), barley growing in the loose soil was subjected to varying time patterns of $\mathrm{O}_{2}$ concentration $\left(0 \%, 2 \%, 6 \%, 10 \%\right.$ or $20 \%$ of $\mathrm{O}_{2}$ in $\left.\mathrm{N}_{2}\right)$ in soil air. The 20-day treatment period was started 26 days after sowing. The $\mathrm{O}_{2}$ concentration was either A) increased at 4-day intervals, B) decreased at 4-day intervals, C) alternated at 2day intervals (= decreasing similarly to $\mathrm{B}$ but returned to $20 \% \mathrm{O}_{2}$ after two days) or D) kept 
Simojoki, A. Supply of oxygen to plant roots in the soil

constant at $20 \%$. Before and after the treatment period the $\mathrm{O}_{2}$ concentration in soil air was maintained at $20 \%$ in all pots. Due to malfunctioning temperature control, the day-time air temperatures during the first month varied between 13 and $20^{\circ} \mathrm{C}$ and the night temperatures were occasionally below $7^{\circ} \mathrm{C}$. In half of the pots, acrylic tubes in the lids were left unsealed to enable certain methodological tests, but as this had only a minor effect on the differences between the aeration treatments only average values are discussed in this paper.

\section{Sampling and measurements}

A porous cup made of sintered polyethylene (height $3.5 \mathrm{~cm}$, volume $6 \mathrm{~cm}^{3}$, pore diameter $100 \mu \mathrm{m}$ ) was buried in the middle of the pot (Fig. 1). Soil air samples $\left(4.5 \mathrm{~cm}^{3}\right)$ were taken $1-2$ times a week from the cup through a narrow Teflon tube attached to a silicon rubber septum. After discarding the first sample, the actual sample was taken for analysis of the gaseous composition by gas chromatography (Jaakkola and Simojoki 1998).

The emissions of $\mathrm{CO}_{2}$ from soil were determined 2-3 times a week by analysing the composition of the air taken from above the soil surface (Fig. 1) and measuring the volumetric flow rate of the incoming gas with a soap film meter. The volumetric emission rate per volume of soil $\left(\mathrm{q}_{\mathrm{s}}\right)$, corrected to normal temperature and pressure $\left(\mathrm{T}_{0}=273.15 \mathrm{~K}, \mathrm{p}_{0}=1013\right.$ mbar $)$, was calculated using the concentration difference $(\Delta \mathrm{c})$ between the incoming $\left(\mathrm{c}_{0}=0\right)$ and outflowing air (c), the flow rate (v), the barometric pressure (p) and the air temperature (T):

$$
q_{s}=\frac{\Delta c v}{V_{\text {soil }}} \frac{T_{0}}{T} \frac{p}{p_{0}}
$$

The cumulative emissions $\left(\mathrm{mg} \mathrm{pot}^{-1}\right)$ of $\mathrm{CO}_{2}-\mathrm{C}$ were calculated by converting the volumetric emission to mass, interpolating linearly between the successive emissions measurements, and summing over the whole experimental period.
The validity of $\mathrm{CO}_{2}$ emission data was assessed by comparing the gas sampling method to a titration method once a week during the first three experiments. In the titration method, the gas flowing out of the pot was bubbled through a $0.5 \mathrm{M} \mathrm{NaOH}$ solution for c. $24 \mathrm{~h}$, and the $\mathrm{CO}_{2}$ trapped in the solution was determined by titration with $1 \mathrm{M} \mathrm{HCl}$. The agreement was good $(r=0.97)$. The lower night temperature and correspondingly slower respiration explain why the titration gave values of about $10 \%$ smaller than the gas sampling.

The dry masses of the shoots and roots of barley were determined 58-61 days after sowing, just before the plants in the open pots began heading (8-10 at Feekes' development scale). In the first three experiments, a few pots were harvested also 11-12 days after sowing. At harvesting, soil samples were taken from each pot at depths of $0-5,5-10$ and $10-15 \mathrm{~cm}$ : half of the soil volume was used for analysing the mass and morphology of the roots (see Simojoki 2000), and the other half for chemical analyses.

\section{Statistical analysis}

The results of the first three experiments (Nos. $1-3$, constant aeration treatments) were pooled before statistical analysis. Because of unexpectedly large water loss from the soil by uptake to the shoots and by transpiration, the data were reclassified to wet and moist treatments. The criterion for classification was $0.05 \mathrm{~m}^{3} \mathrm{~m}^{-3}$ average air space before watering. Separate analyses were done to compare all gas treatments in the loose soil and studying the effect of compaction with the $10 \%$ and $20 \% \mathrm{O}_{2}$ gas treatments. The last experiment (No. 4, time patterns of $\mathrm{O}_{2}$ concentration) was arranged and analysed in a completely randomized manner. Arithmetic means and standard errors of the measured variables and the number of replicates in the treatments are reported. Due to unequal group variances, the statistical significances of treatment effects were analysed non-parametrically (unless stated otherwise in the text) by using the ranks 
Vol. 9 (2000): 303-318.

Table 1. Air-filled porosities and concentrations of $\mathrm{O}_{2}$ in soil air ${ }^{\mathrm{a}}$

\begin{tabular}{|c|c|c|c|c|c|}
\hline & & \multicolumn{2}{|c|}{ Cropped soil } & \multicolumn{2}{|c|}{ Uncropped soil } \\
\hline & & $\begin{array}{l}\text { Air-filled } \\
\text { porosity } \\
\mathrm{m}^{3} \mathrm{~m}^{-3}\end{array}$ & $\begin{array}{c}\text { Concentration of } \\
\mathrm{O}_{2} \text { in soil air } \\
\%\end{array}$ & $\begin{array}{l}\text { Air-filled } \\
\text { porosity } \\
\mathrm{m}^{3} \mathrm{~m}^{-3}\end{array}$ & $\begin{array}{c}\text { Concentration of } \\
\mathrm{O}_{2} \text { in soil air } \\
\%\end{array}$ \\
\hline Loose soil & $\mathrm{O}_{2} \%$ & & & & \\
\hline \multirow{4}{*}{ Wet } & 0 & $0.03 \pm 0.00$ & $0.3 \pm 0.3$ & $0.02 \pm 0.00$ & $0.5 \pm 0.3$ \\
\hline & 2 & $0.04 \pm 0.01$ & $2.0 \pm 0.3$ & $0.02 \pm 0.01$ & $2.0 \pm 1.0$ \\
\hline & 10 & $0.04 \pm 0.01$ & $7.4 \pm 3.1$ & $0.03 \pm 0.01$ & $10.6 \pm 1.1$ \\
\hline & 20 & $0.04 \pm 0.02$ & $16.8 \pm 4.0$ & $0.02 \pm 0.01$ & $20.2 \pm 0.2$ \\
\hline \multirow[t]{4}{*}{ Moist } & 0 & $0.17 \pm 0.01$ & $0.5 \pm 0.8$ & $0.15 \pm 0.00$ & $0.2 \pm 0.2$ \\
\hline & 2 & $0.13 \pm 0.04$ & $1.8 \pm 0.7$ & $0.14 \pm 0.02$ & $1.8 \pm 0.5$ \\
\hline & 10 & $0.19 \pm 0.04$ & $9.9 \pm 0.2$ & $0.14 \pm 0.02$ & $10.3 \pm 0.3$ \\
\hline & 20 & $0.18 \pm 0.06$ & $20.0 \pm 0.6$ & $0.13 \pm 0.02$ & $20.4 \pm 0.1$ \\
\hline \multicolumn{6}{|c|}{ Compact soil } \\
\hline \multirow[t]{2}{*}{ Wet } & 10 & $0.01 \pm 0.01$ & $10.3 \pm 0.6$ & $0.00 \pm 0.00$ & $10.1 \pm 0.9$ \\
\hline & 20 & $0.02 \pm 0.01$ & $20.5 \pm 0.3$ & $0.00 \pm 0.00$ & $20.7 \pm 0.2$ \\
\hline \multirow[t]{2}{*}{ Moist } & 10 & $0.08 \pm 0.01$ & $10.0 \pm 0.5$ & $0.07 \pm 0.00$ & $10.1 \pm 0.3$ \\
\hline & 20 & $0.08 \pm 0.01$ & $20.5 \pm 0.3$ & $0.07 \pm 0.00$ & $20.2 \pm 0.6$ \\
\hline
\end{tabular}

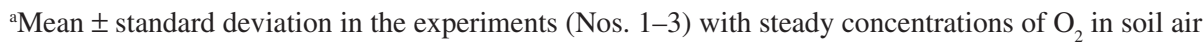

of data in the factorial analysis of variance (Zar 1984 , p. 249). The differences between mean ranks were tested by a non-parametric analog of the Tukey test (Zar 1984, p. 200).

\section{Results}

The average air-filled porosities were $0.02-0.04$ or $0.13-0.19 \mathrm{~m}^{3} \mathrm{~m}^{-3}$ in the loose soil and 0.00 0.02 or $0.07-0.08 \mathrm{~m}^{3} \mathrm{~m}^{-3}$ in the compact soil when wet or moist, respectively (Table 1). In the compact soil, the air-filled porosities may actually have been slightly larger (at most $0.04 \mathrm{~m}^{3}$ $\mathrm{m}^{-3}$ ) due to the swelling of soil on wetting. The concentrations of $\mathrm{O}_{2}$ in soil air were close to those in the applied gas streams (Table 1), except in the loose wet soil barley growing soil where deviations by a maximum of $3 \%$ occurred.

Before starting the wetting and aeration treatments, the dry masses ( \pm standard error) of shoots and roots were $0.54 \pm 0.04 \mathrm{~g}$ and $0.07 \pm 0.02 \mathrm{~g}$ in the loose soil $(\mathrm{n}=8)$, and $0.51 \pm 0.06 \mathrm{~g}$ and $0.01 \pm 0.00 \mathrm{~g}$ in the compact soil $(n=2)$, respectively. In the loose soil, the growth of both shoots and roots was reduced by wetting $(\mathrm{P}<0.05)$ and lowering of $\mathrm{O}_{2}$ concentration in soil air $(\mathrm{P}<0.001)$ (Table 2$)$. The plants grew less at $0 \%$ and $2 \% \mathrm{O}_{2}$ than at $20 \% \mathrm{O}_{2}$ in soil air, whereas the growth at $10 \% \mathrm{O}_{2}$ was not different from that at $20 \% \mathrm{O}_{2}$ (at $\left.\mathrm{P}<0.05\right)$. Compaction reduced the growth of shoots $(\mathrm{P}<0.01)$ and roots $(\mathrm{P}<0.05)$ in both moist and wet soil, regardless of whether the soil air contained $10 \%$ or $20 \% \mathrm{O}_{2}$. In the open pots, the dry mass of shoots was $26.5 \pm 1.3 \mathrm{~g}$ and that of roots $3.1 \pm 0.3 \mathrm{~g}(\mathrm{n}=12)$.

Besides reducing root growth, wetness also changed the distribution of roots at various depths in the loose soil (Fig. 3). When aerated with gas streams containing $10-20 \% \mathrm{O}_{2}$, most roots in the moist soil grew in the deepest soil layer, whereas those in the wet soil preferred the uppermost layer. In fact, some of the roots grew on the surface of the wet soil. In the compact 
Simojoki, A. Supply of oxygen to plant roots in the soil

Table 2. Yields of barley and $\mathrm{CO}_{2}$ emissions from soil ${ }^{\mathrm{a}}$

\begin{tabular}{|c|c|c|c|c|c|c|c|}
\hline & & \multicolumn{2}{|c|}{ Dry matter yield g pot ${ }^{-1}$} & \multicolumn{4}{|c|}{ 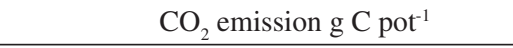 } \\
\hline & & Shoot & Root & $\mathrm{n}$ & Cropped soil & $\mathrm{n}$ & Uncropped soil \\
\hline \multirow{5}{*}{$\begin{array}{l}\text { Loose soil } \\
\text { Wet }\end{array}$} & $\mathrm{O}_{2} \%$ & & & & & & \\
\hline & 0 & 4.5 & 0.08 & 1 & 0.73 & 1 & 0.41 \\
\hline & 2 & $6.7 \pm 0.5$ & $0.06 \pm 0.02$ & 2 & $0.75 \pm 0.04$ & 3 & $0.40 \pm 0.07$ \\
\hline & 10 & $13.0 \pm 4.0$ & $0.22 \pm 0.04$ & 4 & $1.66 \pm 0.34$ & 3 & $0.43 \pm 0.03$ \\
\hline & 20 & $12.7 \pm 2.7$ & $0.74 \pm 0.17$ & 2 & $1.68 \pm 0.26$ & 3 & $0.44 \pm 0.03$ \\
\hline \multirow[t]{4}{*}{ Moist } & 0 & $6.6 \pm 0.8$ & $0.10 \pm 0.01$ & 3 & $0.61 \pm 0.06$ & 1 & 0.25 \\
\hline & 2 & $7.0 \pm 1.0$ & $0.14 \pm 0.01$ & 4 & $0.91 \pm 0.14$ & 3 & $0.39 \pm 0.04$ \\
\hline & 10 & $25.2 \pm 1.2$ & $1.28 \pm 0.25$ & 6 & $3.51 \pm 0.22$ & 3 & $0.40 \pm 0.03$ \\
\hline & 20 & $27.8 \pm 1.7$ & $1.15 \pm 0.16$ & 8 & $3.72 \pm 0.15$ & 3 & $0.43 \pm 0.03$ \\
\hline \multicolumn{8}{|c|}{ Compact soil } \\
\hline \multirow[t]{2}{*}{ Wet } & 10 & $5.7 \pm 0.7$ & $0.26 \pm 0.03$ & 2 & $1.55 \pm 0.17$ & 2 & $0.90 \pm 0.08$ \\
\hline & 20 & $7.2 \pm 1.7$ & $0.32 \pm 0.06$ & 2 & $1.65 \pm 0.06$ & 2 & $1.04 \pm 0.02$ \\
\hline \multirow[t]{2}{*}{ Moist } & 10 & $3.9 \pm 1.8$ & $0.24 \pm 0.16$ & 2 & $1.46 \pm 0.49$ & 2 & $0.91 \pm 0.08$ \\
\hline & 20 & $6.6 \pm 1.6$ & $0.48 \pm 0.39$ & 2 & $1.92 \pm 0.09$ & 2 & $1.32 \pm 0.11$ \\
\hline
\end{tabular}

${ }^{\mathrm{a}}$ Mean \pm standard error in the experiments (Nos. 1-3) with steady concentrations of $\mathrm{O}_{2}$ in soil air

soil, all root growth was restricted to the uppermost soil layer.

The cumulative $\mathrm{CO}_{2}-\mathrm{C}$ emissions in the various treatments (Table 2) were closely related to plant growth. The coefficient of linear correlation between the $\mathrm{CO}_{2}-\mathrm{C}$ emission and the dry matter yield of shoots was $0.92^{* * *}(n=38)$, which was higher $(\mathrm{P}<0.05)$ than that between the dry matter yields of shoots and roots $\left(0.76^{* * *}\right)$. The $\mathrm{CO}_{2}-\mathrm{C}$ emission from the uncropped soil was clearly less than that from the cropped soil; that from the uncropped loose soil was less than half of that from the compact soil.

In the cropped loose soil, the $\mathrm{CO}_{2}$ emission rates from the moist soil at $10 \%$ and $20 \% \mathrm{O}_{2}$ in soil air increased until 5-6 weeks from sowing and started decreasing after that, whereas those from the wet soil varied less during the experiment (Fig. 4). The emissions from the cropped soil supplied with gas streams containing $0 \%$ and $2 \% \mathrm{O}_{2}$, and those from the uncropped soil, slowly decreased with time. In the compact soil, the very large emission rates at the beginning of the experiment declined first quickly and then more slowly in both cropped and uncropped soil (Fig. 5).
In the experiment with different time patterns of $\mathrm{O}_{2}$ concentrations in soil air, the average airfilled porosity in the soil ranged from $0.15 \mathrm{~m}^{3}$ $\mathrm{m}^{-3}$ to $0.20 \mathrm{~m}^{3} \mathrm{~m}^{-3}$, and the $\mathrm{O}_{2}$ concentrations measured in the soil air followed rather closely those supplied in the gas streams. Plant growth was largest at the $\mathrm{O}_{2}$ concentration in soil air constant at $20 \%$ (Table 3). The 4-day period of anoxia in the middle of the experiment, followed by the slow increase of $\mathrm{O}_{2}$ concentration to $20 \%$, reduced shoot growth. Shoot growth was also reduced, if the concentration slowly decreased from $20 \%$ to $0 \%$ during 20 days and then returned to $20 \%$. The latter reduction was however cancelled out by supplying the soil with $20 \%$ $\mathrm{O}_{2}$ every two days. The growth of roots paralleled that of the shoots, although with less significant differences between treatments (Table 3 ). The dry mass of roots in the treatments with the weakest shoot growth was about half of that in the constant $20 \% \mathrm{O}_{2}$ treatment. Root width increased with soil depth, but the mean width was similar in all treatments. The specific volume of the roots was on average $22.7 \mathrm{~cm}^{3} \mathrm{~g}^{-1}$ with no significant differences between treatments and soil depths. 
Vol. 9 (2000): 303-318.

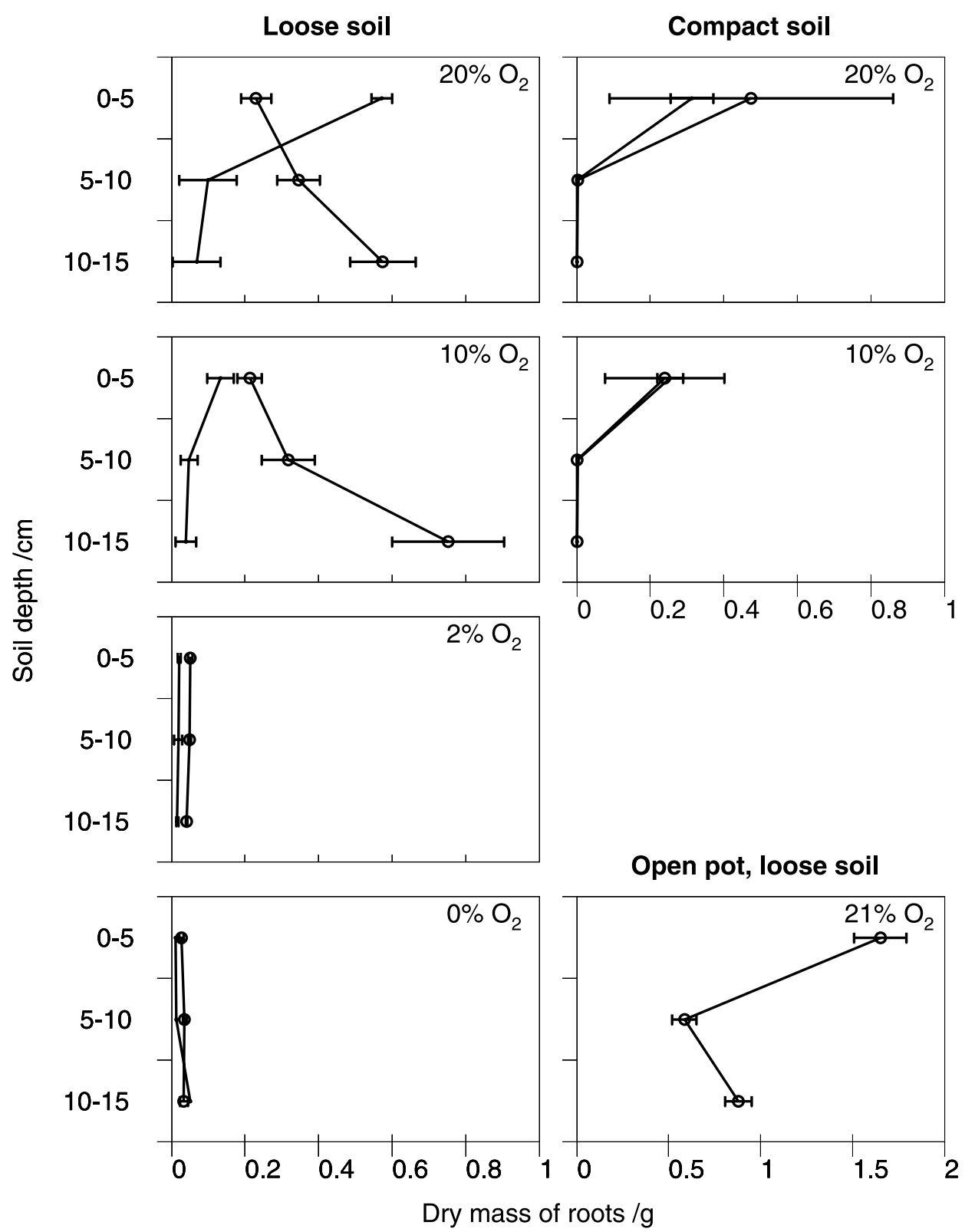

Fig. 3. Distribution of root mass ( \pm standard error) with soil depth. Moist soils are shown by lines with an open circle.

The $\mathrm{CO}_{2}$ emission rates peaked in all treatments on day 34 , after solving the technical problems in the temperature control of the phytotron on day 33 (Fig. 6). Later in the measurement period (days 34-44), only the emission rate from the soil at constant $20 \% \mathrm{O}_{2}$ stayed high. Emission rates were much decreased at $2 \% \mathrm{O}_{2}$ in soil air, and more so at $0 \%$, being however at least 


\section{AGRICULTURAL AND FOOD SCIENCE IN FINLAND}

Simojoki, A. Supply of oxygen to plant roots in the soil

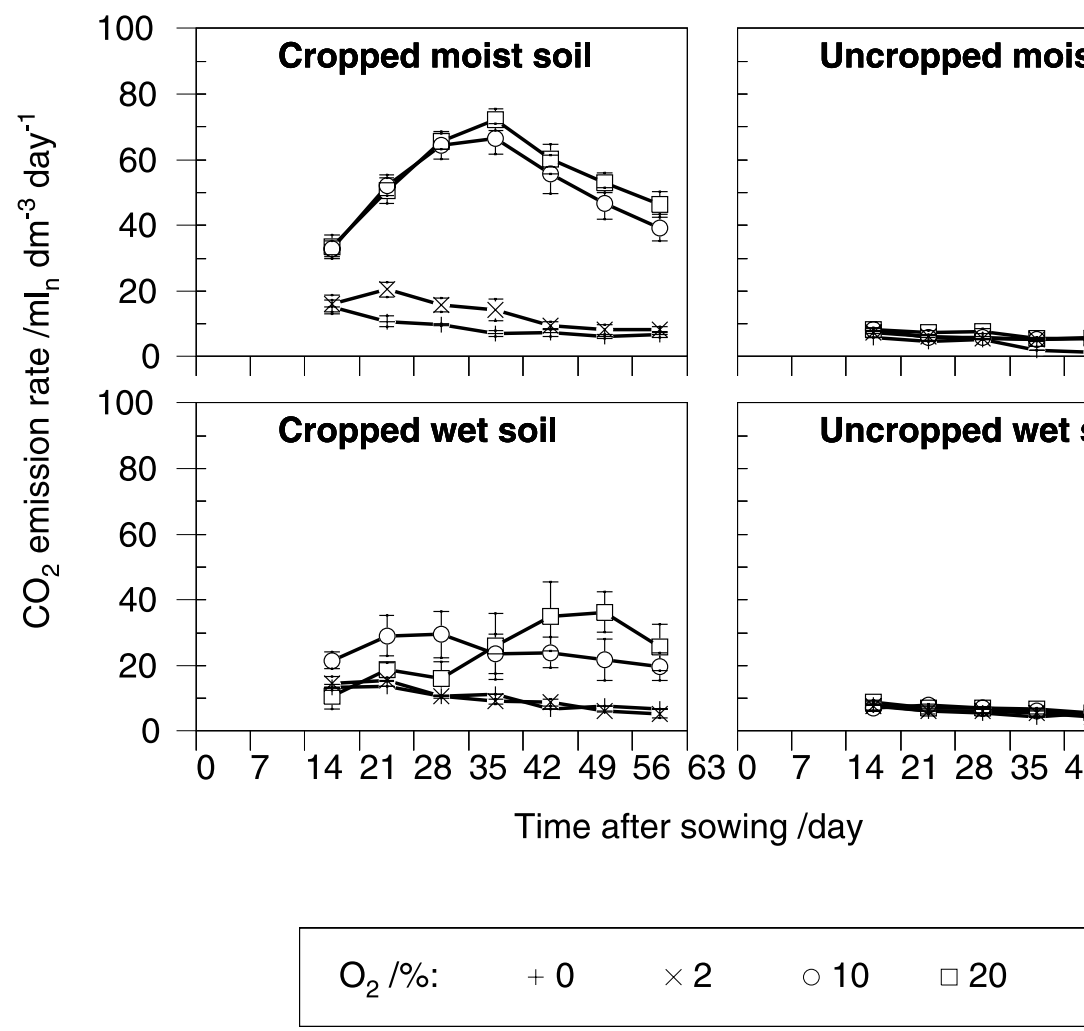

Fig. 4. Emission rates of $\mathrm{CO}_{2}$ from loose soils during the experiments with steady concentrations of $\mathrm{O}_{2}$ in the soil air.

Table 3. Yields and root widths of barley

\begin{tabular}{|c|c|c|c|c|c|}
\hline & \multicolumn{2}{|c|}{$\begin{array}{l}\text { Dry matter yield } \\
\qquad \mathrm{g} \mathrm{pot}^{-1}\end{array}$} & \multicolumn{3}{|c|}{$\begin{array}{l}\text { Root width } \\
\mu \mathrm{m}\end{array}$} \\
\hline & Shoot & Root & $0-5 \mathrm{~cm}$ & $5-10 \mathrm{~cm}$ & $10-15 \mathrm{~cm}$ \\
\hline Increasing $\mathrm{O}_{2}$ & 13.4 & 0.8 & 228 & 270 & 283 \\
\hline Decreasing $\mathrm{O}_{2}^{2}$ & 17.9 & 0.7 & 216 & 245 & 308 \\
\hline Alternating $\mathrm{O}_{2}$ & 23.8 & 1.3 & 223 & 260 & 321 \\
\hline Constant $\mathrm{O}_{2}$ & 25.8 & 1.6 & 233 & 274 & 314 \\
\hline $\mathrm{HSD}^{\mathrm{b}}$ & 6.5 & 0.9 & & 38 & \\
\hline
\end{tabular}

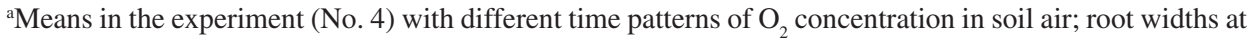
various soil depths; $n=4$

${ }^{\mathrm{b}} \mathrm{HSD}$ honestly significant difference $(\mathrm{P}<0.05)$ 
Vol. 9 (2000): 303-318.

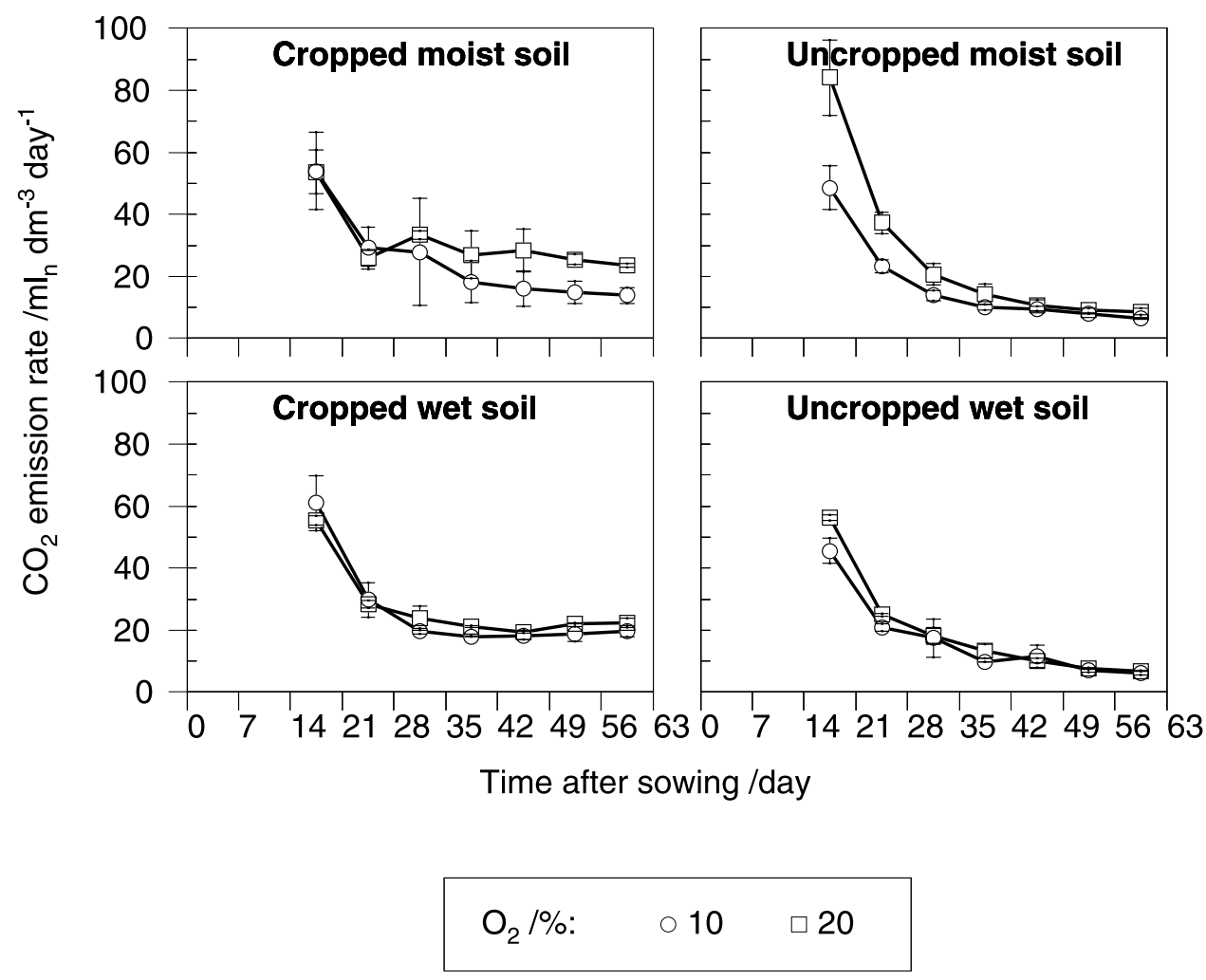

Fig. 5. Emission rates of $\mathrm{CO}_{2}$ from compact soils during the experiments with steady concentrations of $\mathrm{O}_{2}$ in the soil air.

partly restored on returning the concentration to 20\% (Figs. 6 and 7).

\section{Discussion}

\section{Respiration and growth of barley}

The results indicate that concentrations above $6 \% \mathrm{O}_{2}$ in soil air are adequate for the respiration and growth of barley roots at moderate moisture contents in loose soil. In wet and compact soils, however, growth is impaired even when the soil is constantly flushed with gas streams containing $20 \% \mathrm{O}_{2}$. The reduced yields in the wet soil can be partly attributed to an inadequate oxygen supply, as increasing the $\mathrm{O}_{2}$ concentration from $0-2 \%$ to $20 \%$ (to $17 \%$ in soil air) alleviated the reduction. Conversely, compaction of soil decreased the yields and impeded the growth of roots regardless of wetting and aeration treatments.

Shoot mass in the well-aerated treatments of this study were similar to those in open pots receiving no artificial aeration, but root masses were reduced to less than half, probably because the growth of adventitious roots that would have emerged above the lid was blocked. The results are similar to those of Anderson-Taylor and Marshall (1983), who found the mass of seminal roots to be about $40 \%$ of the total root mass at an age of 12 week. In any case, plant growth was more closely related to respiration rather than to mere mass of roots. 


\section{AGRICULTURAL AND FOOD SCIENCE IN FINLAND}

Simojoki, A. Supply of oxygen to plant roots in the soil
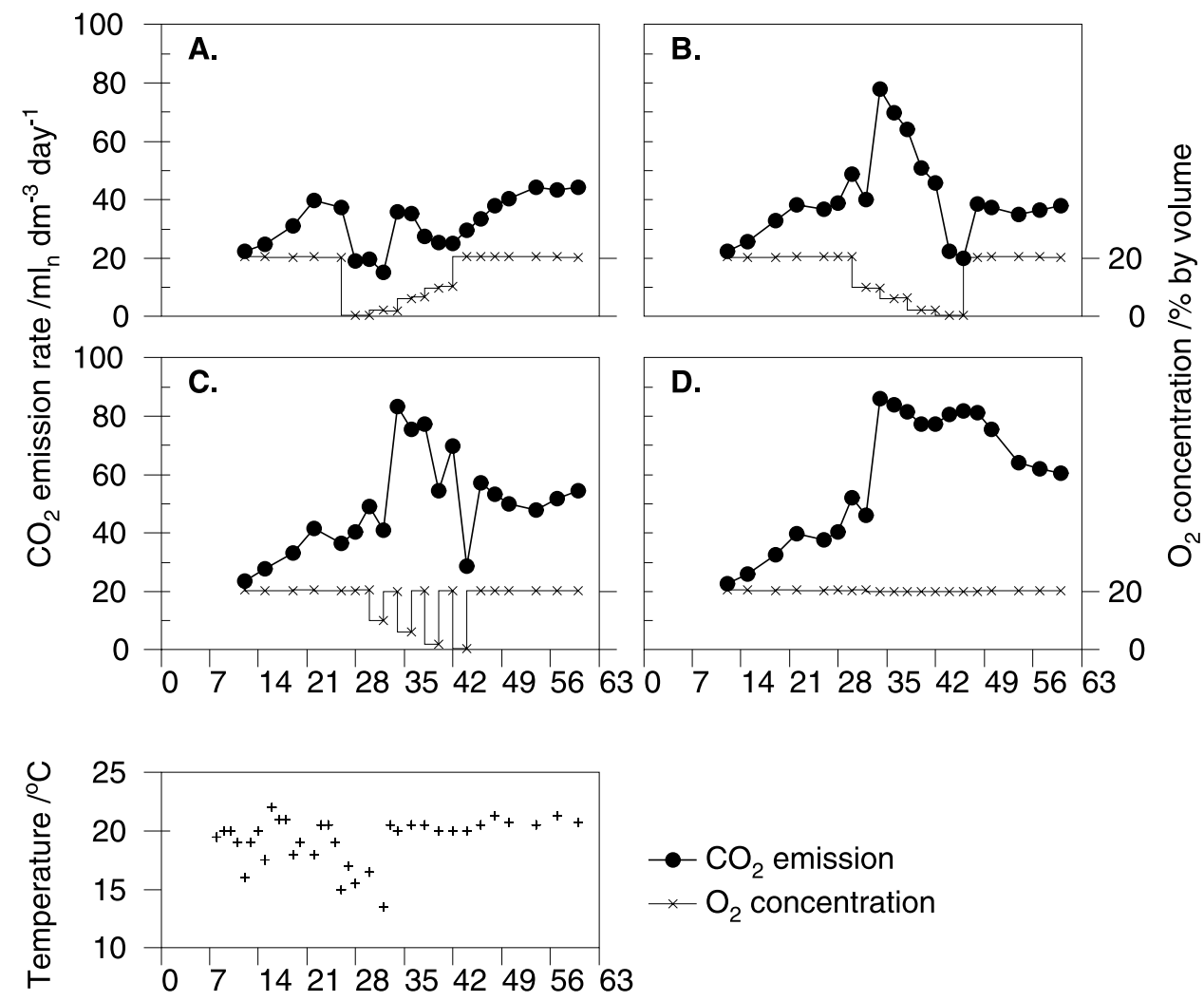

Time after sowing /day

Fig. 6. Emission rates of $\mathrm{CO}_{2}$ from soils and day-time air temperatures during the experiment with A) increasing, B) decreasing, C) alternating or D) constant $\mathrm{O}_{2}$ concentration in the soil air during the treatment period.

The data indicate that the critical $\mathrm{O}_{2}$ concentration in soil air below which the respiration and growth of barley roots decrease in the loose soil was between $2 \%$ and $6 \%$ in the moist soil and above $17 \%$ in the wet soil. In the compact soil, increasing the concentrations from $10 \%$ to $20 \%$ did not improve plant growth or respiration regardless of soil wetness, suggesting that these concentrations were above the critical value.

\section{Critical $\mathrm{O}_{2}$ concentration in soil air}

In this study, the respiration of roots was thought to depend mainly on the diffusive flux of $\mathrm{O}_{2}$ from soil air to the roots, controlled by the thickness of water-film around the roots (Lemon 1962). The thickness was thought to equal the distance from the root surface to nearest air-filled pores. Plant growth was expected to be impaired, if the $\mathrm{O}_{2}$ flux was slow enough to limit the respiration of the roots. Multicylindrical radial steady-state models by Lemon (1962) and Armstrong and Beckett (1985) were applied to calculate the theoretical critical $\mathrm{O}_{2}$ concentrations (COC) in soil air. Values of radii, respiration rates and diffusion coefficients for three coaxial cylindrical shells (stele, cortex, water film) were needed.

The root radius $\mathrm{R}_{\text {root }}=150 \mu \mathrm{m}$ was chosen based on the measurements in this study (Table 3, 
Vol. 9 (2000): 303-318.

Simojoki, unpublished). The stele radius equalled half of root radius. The thickness of the water-film was estimated using the water retention data (Fig. 2). An empirical function $\theta=\mathrm{f}\left(\psi_{\mathrm{m}}\right)$ relating the volumetric water content $\theta$ and the matric suction $\psi_{\mathrm{m}}$ was differentiated to calculate the differential water capacity $C_{w}=d \theta / d \psi_{m}$. Assuming a regular array of cylindrical pores in the soil, the length density of air-filled pores $\mathrm{n}\left(\psi_{\mathrm{m}}\right)$ (= the number of air-filled pores per unit area), was calculated by integrating

$n\left(\Psi_{m}\right)=\int_{0}^{\Psi_{m}} \frac{C_{w}\left(\Psi_{m}\right)}{\pi R^{2}\left(\Psi_{m}\right)} d \Psi_{m}$

where $\mathrm{R}\left(\psi_{\mathrm{m}}\right)=2 \sigma / \psi_{\mathrm{m}}$ (surface tension of water $\sigma=72.75 \mathrm{mN} \mathrm{m}^{-1}$ at $20^{\circ} \mathrm{C}$ ). Assuming each air-filled pore was surrounded by a cylindrical soil volume, the average distance $\mathrm{d}_{\text {pore }}$ between the pore centres was calculated (see Barley 1970), and the thickness $d$ of the water film was approximated by

$$
d=d_{\text {pore }}-2 R\left(\Psi_{m}\right)=2\left(\sqrt{\frac{1}{\pi n\left(\Psi_{m}\right)}}-R\left(\Psi_{m}\right)\right)
$$

The respiration rate of roots $\mathrm{q}=150 \times 10^{-6} \mathrm{~m}^{3}$ $\mathrm{m}^{-3} \mathrm{~s}^{-1}$ was estimated by the maximum root-induced respiration rate (the maximum difference between cropped and uncropped soils) divided by the volume of roots, assuming that $\mathrm{O}_{2}$ consumption equaled $\mathrm{CO}_{2}$ production. The volume of the roots was calculated from the mass and specific volume of the roots, assuming that the mass of the roots at the time of maximum respiration was half that at the end of the experiment. When calculating COCs, it was assumed that 1) only the roots respire, or that 2) half of the rootinduced respiration occurs in roots and half inside the water-film. Respiration rates in stele and cortex were assumed to be uniform $\left(\mathrm{q}_{\text {stele }}=\right.$ $\left.\mathrm{q}_{\text {cortex }}\right)$.

The diffusion coefficients of $\mathrm{O}_{2}$ in both the stele and cortex $\mathrm{D}_{\text {stele }}=\mathrm{D}_{\text {cortex }}$ were assumed to be half of that in pure water $\left(D_{w}=2.1 \times 10^{-9} \mathrm{~m}^{2}\right.$ $\mathrm{s}^{-1}$ at $20^{\circ} \mathrm{C}$ ), based on the range of estimates $\left(1.4 \times 10^{-10}-2.1 \times 10^{-9} \mathrm{~m}^{2} \mathrm{~s}^{-1}\right)$ adopted by other authors (Wanner 1945, Armstrong and Beckett 1985). The diffusion coefficient in the water film

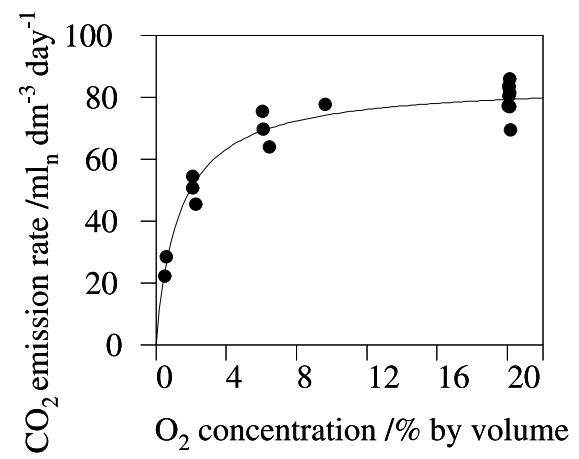

Fig. 7. The emission of $\mathrm{CO}_{2}$ from soil $\left(\mathrm{q}_{\mathrm{s}}\right)$ as a function of $\mathrm{O}_{2}$ concentration (c) at the gas outlet on days 33-44 in the experiment in the treatments B, C and D (decreasing, alternating and constant $\mathrm{O}_{2}$ concentration in soil air, respective1y, see Fig. 6). The points are means of four replicates. Parameters of an empirical Michaelis-Menten curve $\mathrm{q}_{\mathrm{s}}=\mathrm{q}_{\max }$ $\mathrm{c} /(\mathrm{K}+\mathrm{c})$ fitted to the data are $\mathrm{q}_{\max }=85 \mathrm{ml} \mathrm{dm}^{-3}$ day $^{-1}, \mathrm{~K}=$ $1.4 \%, \mathrm{n}=18, \mathrm{R}^{2}=0.99$.

$\mathrm{D}_{\text {film }}=0.30 \times \mathrm{D}_{\mathrm{w}}$ was estimated by

$D_{f i l m}=\frac{D}{D_{0}} \times D_{w}=f\left(\Phi_{\text {film }}\right) D_{w}=f\left(\frac{\Phi-\varepsilon}{1-\varepsilon}\right) D_{w}$

using empirical expressions for the relative diffusion coefficient $\mathrm{D} / \mathrm{D}_{0}$ (Millington and Quirk 1960, Penman 1940) as a function of the porosity in the water film $\phi_{\text {film }}$, which was calculated from total porosity $\phi$ and air-filled porosity $\varepsilon$ by relating the pore space inside the water-film to its own soil volume (see Currie 1965).

The $\mathrm{O}_{2}$ concentrations at the outer edge of the water film $\left(\mathrm{C}_{0}\right)$ and in soil $\operatorname{air}\left(\mathrm{C}_{\mathrm{a}}\right)$ were considered to be in equilibrium so that $\mathrm{C}_{0}=\alpha_{\mathrm{B}} \mathrm{C}_{\mathrm{a}}$ (Bunsen's absorption coefficient $\alpha_{B}=0.0333$ at $20^{\circ} \mathrm{C}$ ). The range of COCs in soil air was estimated by calculating the smallest concentration at which all the root is oxic, and the largest at which all the stele is anoxic.

The length densities of air-filled pores and thicknesses of the water films are estimated in Fig. 8. The magnitude of COCs in soil air depends strongly on the water-film thickness (Table 4). Compaction increases the critical concentrations in the wet soil, but in the moist soil the effect disappears although air-filled porosity is 
Simojoki, A. Supply of oxygen to plant roots in the soil

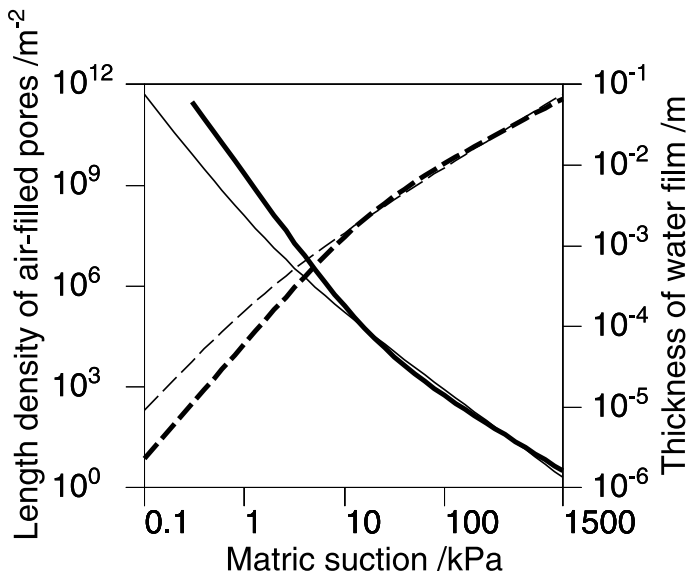

Fig. 8. Computed values of pore length density (dashed line) and thickness of water film (solid line) as a function of matric suction in loose (thin line) and compact (thick line) soils.

reduced by compaction. When there is no water-film around the roots COCs are still smaller. The theoretical COCs in soil air agree rather well with the empirical data, especially if half of the root-induced respiration is assumed to occur in the water-film. However, the predicted COCs of $11-15 \%$ in the loose wet soil and those of 15$19 \%$ in the wet compact soil are slightly smaller than the empirical observations.

The values of COC are not very sensitive to variations in the parameters. Although the sensitivity increases with wetness, even large variation in the parameters is unlikely to cause further disagreement between theory and observations (Fig. 9). On the other hand, such a range of variation may explain part of the observed discrepancies. Those in the loose wet soil can be explained by assuming slightly smaller diffusion coefficients in the roots and water-films and more rapid respiration in the roots. Thus, if more than half of the root-induced respiration occurred in roots, the COCs would be correspondingly larger.

Disagreement between theory and observations could also be caused by violating the assumptions of the theory. In the compact soil, the

Table 4. Water-film thicknesses and critical $\mathrm{O}_{2}$ concentrations in soil air ${ }^{\mathrm{a}}$

\begin{tabular}{lccccc}
\hline & $\begin{array}{c}\text { Matric } \\
\text { suction } \\
\mathrm{kPa}\end{array}$ & $\begin{array}{c}\text { Air-filled } \\
\text { porosity } \\
\mathrm{m}^{3} \mathrm{~m}^{-3}\end{array}$ & $\begin{array}{c}\text { Thickness of } \\
\text { water film } \\
\mathrm{mm}\end{array}$ & $\begin{array}{c}\text { Critical } \mathrm{O}_{2} \text { concentrations } \\
\text { in soil air }\end{array}$ \\
Loose soil & 1 & & & 2.36 & $\begin{array}{c}\text { PRR }^{\mathrm{d}}=100 \\
\text { PRR }=50\end{array}$ \\
Compact soil & 10 & 0.039 & 0.15 & $18-25$ & $11-15$ \\
& 1 & 0.147 & 7.83 & $25-34$ & $4-5$ \\
No water film & 10 & 0.003 & 0.18 & $6-9$ & $4-6$ \\
\hline
\end{tabular}

${ }^{a}$ Computed for loose and compact soils at matric suctions corresponding roughly to the wet $(1 \mathrm{kPa})$ and moist $(10 \mathrm{kPa})$ treatments in this study, and around roots without any water-film

${ }^{\mathrm{b} C}$ Computed with multicylindrical radial symmetric models (Lemon 1962, Armstrong and Beckett 1985); $\mathrm{R}_{\text {root }}=0.15 \mathrm{~mm}$ root radius; $\mathrm{q}=150 \times 10^{-6} \mathrm{~m}^{3} \mathrm{~m}^{-3} \mathrm{~s}^{-1}$ total root-induced respiration rate per root volume; $\mathrm{D}_{\mathrm{w}}=2.1 \times 10^{-9} \mathrm{~m}^{2} \mathrm{~s}^{-1}, \mathrm{D}_{\text {root }}=\mathrm{D}_{\text {stele }}=\mathrm{D}_{\text {cortex }}=0.5 \times \mathrm{D}_{\mathrm{w}}$ and $\mathrm{D}_{\text {film }}=0.3 \times \mathrm{D}_{\mathrm{w}}$ are the diffusion coefficients of oxygen in the water, root and water film, respectively. Below the smaller critical concentration the stele $\left(\mathrm{R}_{\text {stele }}=0.5 \times \mathrm{R}_{\text {root }}\right)$ becomes completely anoxic, and above the larger critical concentration the root remains completely oxic

${ }^{\mathrm{c}}$ Estimated from the water retention curves (see Figs. 2 and 8)

${ }^{\mathrm{d} P R R}$ percentage root respiration $=$ the proportion of the actual root respiration to the total root-induced respiration (root + water film) 
Vol. 9 (2000): 303-318.

growth of roots was restricted to near the soil surface probably due to large mechanical impedances deeper in the soil. In contrast to the assumptions of the theory, the roots in fact grew partly on the surface of the wet soil, where the water-films around the roots were probably much thinner than in the soil. Thus, also COCs were smaller than in the soil, probably less than $10 \%$, which explains why no difference was observed between $10 \%$ and $20 \% \mathrm{O}_{2}$ treatments in the wet soil. Also, any increases in soil air-filled porosity due to swelling of soil could have decreased the COCs similarly.

For simplicity, as we had no measurements of our own, respiration and diffusion properties were assumed to be uniform in the roots, and the epidermal-hypodermal cylinder was lumped in with the cortex proper. In reality, respiration is probably more rapid in the rather aporous stele than in the more porous cortex (except for perhaps at the root apex), whereas diffusion is more rapid in the cortex than in the stele (Armstrong and Beckett 1985, Armstrong et al. 1991, Gibbs et al. 1998). Assuming $D_{\text {cortex }}=60 \times D_{\text {stele }}$ (corresponding to the radial diffusivity in the cortex $6.5 \times 10^{-8} \mathrm{~m}^{2} \mathrm{~s}^{-1}$ by Armstrong and Beckett 1985) and $\mathrm{q}_{\text {stele }}=3 \times \mathrm{q}_{\text {cortex }}$, the upper COCs in Table 4 would decrease by at most $1 \%$. The corresponding decreases in the lower COCs, however, would be this small only in the moist soil, whereas in the loose and compact wet soils they would be about $3 \%$ and $5 \%$, respectively (at a percentage root respiration of $50 \%$, and twice that much at $100 \%$; data not shown). Thus, the COCs as calculated in Table 4 are overestimates. They may nevertheless be appropriate for assessing the minimum requirements of oxygen concentration in soil air, as microelectrode studies (Gibbs et al. 1998) have shown that even partial anoxia in the stele can much reduce root elongation and energy-dependent solute transport into the $x y-$ lem.

Irregular distribution of air-filled pores in the soil violates the assumed radial symmetric diffusion of $\mathrm{O}_{2}$ to roots and may increase the COCs. Irregularities are probably larger in wet soil, which may explain the smaller than expected

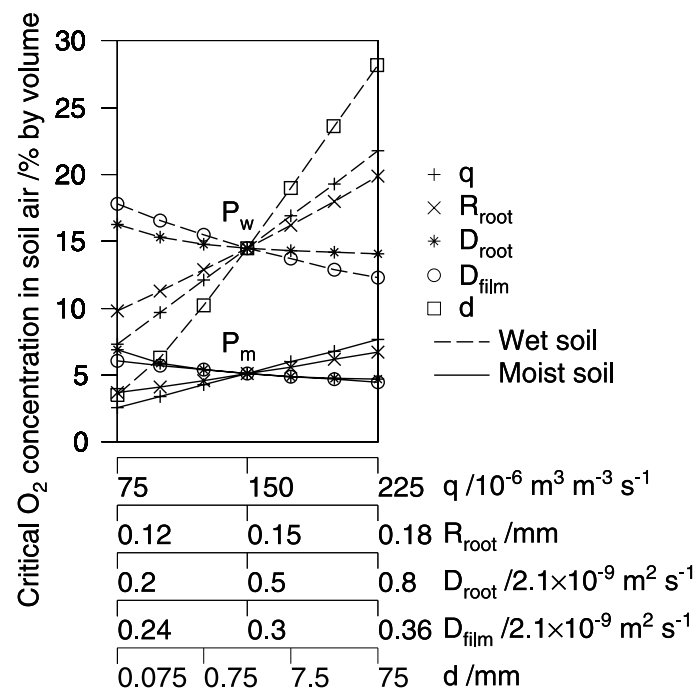

Fig. 9. Sensitivity of calculated COCs to the variation of the model parameters in moist ( $\mathrm{d}$ at $\mathrm{P}_{\mathrm{m}} 0.15 \mathrm{~mm}$ ) and wet (d at $\mathrm{P}_{\mathrm{w}} 2.36 \mathrm{~mm}$ ) soils. Parameters: $\mathrm{q}$ root-induced respiration rate, $\mathrm{R}_{\text {root }}$ root radius, $\mathrm{D}_{\text {root }}$ diffusion coefficient of $\mathrm{O}_{2}$ in root, $\mathrm{D}_{\text {film }}$ diffusion coefficient of $\mathrm{O}_{2}$ in water-film, $\mathrm{d}$ water-film thickness.

growth of barley in the wet loose soil at $20 \% \mathrm{O}_{2}$. The diffusion paths in soil are never strictly radial symmetric, as only parts of the outer edge of the water-film are in contact with the gas phase. Relatively few air-filled pores around the roots may however suffice for nearly the maximal flux, because smaller contact areas are compensated for by greater concentration gradients. Only if the uneven water-film thickness causes asymmetric sectoral blocking of the diffusion path may COCs increase considerably (Armstrong and Beckett 1985, de Willigen and van Noordwijk 1984, van Noordwijk and de Willigen 1984). Further, if the roots are heavily clumped due to irregularities, inter-root competition limits the uptake of nutrients (Baldwin et al. 1972) and other resources by roots.

Non-uniform respiration rates in roots can also increase COC. The respiration rates at apical meristems are typically about twice the average respiration rate of roots (Machlis 1944, Luxmoore et al. 1970). Decreased respiration in 


\section{Simojoki, A. Supply of oxygen to plant roots in the soil}

hypoxic apices may however be compensated for by other parts of the roots, which makes the respiration rates more uniform at increasing hypoxia. On the other hand, COCs for root growth would then be larger than that for respiration. This could be another explanation for the discrepancy between theory and the observations in the wet loose soil.

Some internal diffusion of oxygen occurs from shoots to roots in all plant species, but this is generally insufficient to sustain the activities of extensive root systems of non-wetland species (Armstrong 1979), even if enhanced by the formation of aerenchyma (Drew et al. 1985, Thomson and Greenway 1991, Gibbs et al. 1995). This was confirmed also in this study. Minor internal aeration may however explain why the shoots of barley grew to some extent even in anoxic soil. On the other hand, when calculating the minimum requirements of oxygen concentration in soil air, it is justified to neglect internal aeration to obtain estimates which are on the safe side.

The air samples probably came from the largest air pores not in direct contact with the waterfilm. The concentration gradients across such short distances must however be small, as the diffusion of $\mathrm{O}_{2}$ is $10^{4}$ faster in air than in water. Also the transient changes of $\mathrm{O}_{2}$ diffusion to roots hardly affected the results (see de Willigen and van Noordwijk 1984).

\section{Conclusions}

This study has shown that concentrations as low as $6 \% \mathrm{O}_{2}$ in soil air are adequate for respiration and growth of barley roots in soils at moderate moisture contents. In loose soil, $\mathrm{CO}_{2}$ emission $\left(\mathrm{q}_{\mathrm{s}}\right)$ versus $\mathrm{O}_{2}$ concentration (c) followed
Michaelis-Menten equation $\mathrm{q}_{\mathrm{s}}=\mathrm{q}_{\max } \mathrm{c} /(\mathrm{K}+\mathrm{c})$ with a $\mathrm{K}$ value of $1.4 \%$. Conversely, in wet soils with less than $5 \%$ air space plant growth is impaired even if the soil is aerated with a gas stream containing $20 \% \mathrm{O}_{2}$. The results also indicate that heavy compaction can impair plant growth by increasing the mechanical impedance deeper in the soil and thus restricting the growth of roots to a small volume near the soil surface.

The results compare fairly well with the COCs calculated by a simple multicylindrical model, in which the water-film thickness around the roots was estimated using soil water retention data. The approach seems to give reasonable estimates of the minimum requirements of $\mathrm{O}_{2}$ concentrations in soil air for the respiration and growth of plant roots at least in coarse-textured soils, such as the one in this study. It is less certain to what extent the model can be applied to soils with secondary structures. However, even though the pore geometry in clays can be complicated (Bruand and Prost 1987), earthworm channels and old root channels are nearly cylindrical. As the largest pores are the most important for the aeration of wet soils, the model may be applicable to wet clays as well. The model can be easily combined with larger models of plant growth and soil aeration to identify soil layers where aeration is limiting.

Acknowledgements. I thank Prof. Antti Jaakkola for advice and Susanna Hyvärinen for technical assistance during all stages of the study. I am grateful also to Jari Anttila, Harri Eskelin, Marjatta Koivisto, Eeva Kontkanen, Astrid Kovaljeff, Heli Kyrönkari, Riitta Lemola, Päivi Nevalainen, Harri Pihl, Riikka Simojoki and Timo Simojoki for their technical assistance, the Kotkaniemi Experimental Farm of Kemira Oy for providing the soil, and especially Martti Lippo for transporting it to Viikki. I also thank the Department of Agricultural Engineering for good co-operation and Donald Smart for English language revision. Financial support from the Academy of Finland is gratefully acknowledged. 


\section{References}

Anderson-Taylor, G. \& Marshall, C. 1983. Root-tiller interrelationships in spring barley (Hordeum distichum (L.) Lam.). Annals of Botany 51: 47-58.

Armstrong, W. 1979. Aeration in higher plants. Advances in Botanical Research 7: 225-332.

- \& Beckett, P.M. 1985. Root aeration in unsaturated soil: a multi-shelled mathematical model of oxygen diffusion and distribution with and without sectoral wet-soil blocking of the diffusion path. New Phytologist 100: 293-311.

- , Strange, M.E., Cringle, S. \& Beckett P.M. 1994. Microelectrode and modelling study of oxygen distribution in roots. Annals of Botany 74: 287-299.

Baldwin, J.P., Tinker, P.B. \& Nye, P.H. 1972. Uptake of solutes by multiple root systems from soil. Plant and Soil 36: 693-708.

Barley, K.P. 1970. The configuration of the root system in relation to nutrient uptake. Advances in Agronomy 22: 150-201.

Bruand, A. \& Prost, R. 1987. Effect of water content on the fabric of a soil material: an experimental approach. Journal of Soil Science 38: 461-472.

Currie, J.A. 1965. Diffusion within soil microstructure. A structural parameter for soils. Journal of Soil Science 16: 279-289.

de Willigen, P. \& van Noordwijk, M. 1984. Mathematical models on diffusion of oxygen to and within plant roots, with special emphasis on effects of soil-root contact. I. Derivation of the models. Plant and Soil 77: 215-231.

Drew, M.C. 1990. Sensing soil oxygen. Plant Cell and Environment 13: 681-693.

- 1992. Soil aeration and plant root metabolism. Soil Science 154: 259-268.

- , Saglio, P.H. \& Pradet, A. 1985. Larger adenylate energy charge and ATP/ADP ratios in aerenchymatous roots of Zea mays in anaerobic media as a consequence of improved internal oxygen transport. Planta 165: 51-58.

Gibbs, J., de Bruxelle, G., Armstrong, W. \& Greenway, H. 1995. Evidence for anoxic zones in 2-3 mm tips of aerenchymatous maize roots under low $\mathrm{O}_{2}$ supply. Australian Journal of Plant Physiology 22: 723730.

- , Turner, D.W., Armstrong, W., Darwent, M.J. \& Greenway, H. 1998. Response to oxygen deficiency in primary maize roots. I. Development of oxygen deficiency in the stele reduces radial solute transport to the xylem. Australian Journal of Plant Physiology 25: 745-758.

Gliski, J. \& Stpniewski, W. 1985. Soil Aeration and Its Role for Plants. Boca Raton: CRC Press. 229 p.

Hutchins, L.M. 1926. Studies on the oxygen-supplying power of the soil together with quantitative observations on the oxygen-supplying power requisite for seed germination. Plant Physiology 1: 95-150.

Jaakkola, A. \& Simojoki, A. 1998. Effect of soil wetness on air composition and nitrous oxide emission in a loam soil. Agricultural and Food Science in Finland 7: 491-505.

Lemon, E.R. 1962. Soil aeration and plant root relations. I. Theory. Agronomy Journal 54: 167-170.

Luxmoore, R.J., Stolzy, L.H. \& Letey, J. 1970. Oxygen diffusion in the soil-plant system. II. Respiration rate, permeability and porosity of consecutive excised segments of maize and rice roots. Agronomy Journal 62: 322-324.

Machlis, L. 1944. The respiratory gradient in barley roots. American Journal of Botany 31: 281-282.

Millington, R.J. \& Quirk, J.P. 1960. Transport in porous media. Transactions of International Congress of Soil Science 7th, Madison, Wisconsin. I: 97-106.

Penman, H.L. 1940. Gas and vapour movements in the soil. I. The diffusion of vapours through porous solids. Journal of Agricultural Science, London 30: 437462.

Simojoki, A. 2000. Calibration of a desktop scanner and digital image analysis procedure for quantification of root morphology. Agricultural and Food Science in Finland 9: 223-230.

- \& Jaakkola, A. 2000. Effect of nitrogen fertilization, cropping and irrigation on soil air composition and nitrous oxide emission in a loamy clay. European Journal of Soil Science 51: 413-424.

Soil Survey Staff 1992. Keys to Soil Taxonomy. 5th ed. SMSS technical monograph No.19. Blacksburg, Virginia: Pocahontas Press, Inc. 556 p.

Stępniewski, W., Gliński, J. \& Ball, B.C. 1994. Effects of compaction on soil aeration properties. In: Soane, B.D. \& van Ouwerkerk, C. (eds.). Soil Compaction in Crop Production. Amsterdam, Elsevier. p. 167-189.

van Noordwijk, M. \& de Willigen, P. 1984. Mathematical models on diffusion of oxygen to and within plant roots, with special emphasis on effects of soil-root contact. II. Applications. Plant and Soil 77: 233-241.

Thomson, C.J. \& Greenway, H. 1991. Metabolic evidence for stelar anoxia in maize roots exposed to low $\mathrm{O}_{2}$ concentrations. Plant Physiology 96: 1294-1301.

Van Genuchten, M.Th. 1980. A closed-form equation for predicting the hydraulic conductivity of unsaturated soils. Soil Science of America Journal 44: 892-898.

Vartapetian, B.B. \& Jackson, M.B. 1997. Plant adaptations to anaerobic stress. Annals of Botany 79 (Supplement A): 3-20.

Wanner, H. 1945. Sauerstoffdiffusion als begrenzender Faktor der Atmung von Pflanzenwurzeln. Vierteljahrschrift der Naturforsch Gesellschaft in Zürich 90: 98119.

Zar, J.H. 1984. Biostatistical Analysis. 2nd ed. Englewood Cliffs, NJ: Prentice-Hall. 718 p. 


\title{
AGRICULTURAL AND FOOD SCIENCE IN FINLAND
}

Simojoki, A. Supply of oxygen to plant roots in the soil

\section{SELOSTUS}

\section{Maan hengityksen ja ohran kasvun reagointi hapensaannin muutoksiin maassa}

\author{
Asko Simojoki \\ Helsingin yliopisto
}

Happi diffundoituu kuivan maan kasvilajien juuriin pääasiassa maan ilmasta. Juuret voivat kärsiä hapenpuutteesta, jos maan ilmanvaihto heikkenee liiallisen tiivistämisen tai märkyyden vuoksi. Vaikka juurten hapenpuutteen syntyyn ja seurauksiin liittyvät mekanismit tunnetaan melko hyvin, lisätutkimusta tarvitaan maan happitilan kytkemiseksi paremmin kasvin kasvuun. Juurten heikentyneen hapensaannin vaikutuksia maan hengitykseen ja ohran versojen kasvuun tutkittiin astiakokeissa koemaana karkea hieta. Maan ilman koostumusta säädeltiin huuhtomalla tiiviydeltään (kuiva irtotiheys 1,4 tai 1,6 $\mathrm{Mg} \mathrm{m}^{-3}$ ) ja märkyydeltään (ilmatilaa 0-5\% tai $>5 \%$ ) erilaista maata kaasuvirtauksilla, joiden happipitoisuus tunnettiin (0 \%, $2 \%, 6 \%, 10 \%$ tai $20 \% \mathrm{O}_{2} \mathrm{~N}_{2}$-kaasussa). Löyhässä, kosteassa maassa ohran kasvu heikkeni vasta
0-2 \%:n, mutta märässä maassa jo $20 \%$ :n happipitoisuudessa. Tiiviissä maassa kasvin kasvu oli heikkoa riippumatta maan märkyydestä ja ilmastamisesta. Löyhässä kosteassa maassa, jossa kasvoi ohraa, hengitys ei vielä hidastunut $6 \%$ :n happipitoisuudessa mutta hidastui selvästi $0-2 \%$ :n pitoisuuksissa. Tulokset sopivat verraten hyvin yhteen diffuusiomallilla laskettujen kriittisten happipitoisuuksien kanssa, kun hapen oletettiin diffundoituvan säteensuuntaisesti maan ilmasta juureen vesikalvon lävitse. Vesikalvon paksuus estimoitiin maan vedenpidätysominaisuuksista. Lähestymistapa vaikuttaa soveltuvan maan ilman happipitoisuuksien vähimmäisvaatimusten arvioimiseen ainakin karkealajitteisissa maissa, mutta saattaa soveltua myös esimerkiksi märkään savimaahan. 